\title{
THE RELIABILITY OF RADIOCARBON DATING BURIED SOILS
}

\section{A. ORLOVA and V. A. PANYCHEV}

United Institute of Geology, Geophysics and Mineralogy, Universitetsky pr., 3, Novosibirsk 90, 630090 Russia

\begin{abstract}
Variable ${ }^{14} \mathrm{C}$ ages of paleosol organic matter (OM) cause difficulties in interpreting ${ }^{14} \mathrm{C}$ data. We attempt to determine the reliability of $\mathrm{OM}^{14} \mathrm{C}$ dates by examining different carbon-containing materials from soil horizons and paleosol fractions.
\end{abstract}

\section{INTRODUCTION}

Since the first ${ }^{14} \mathrm{C}$ age determination of soil organic matter (OM) (Tamm and Östlund 1960), the problems of ${ }^{14} \mathrm{C}$ data interpretation have been widely discussed (Arslanov 1987; Arslanov et al. 1970; Arslanov and Kozyreva 1976; Gerasimov and Chichagova 1971; Zavelskiy 1975; Chichagova 1985; Scharpenseel 1971; Campbell et al. 1967; Costin and Polach 1969; Geyh, Bensler and Roeschman 1971; Polach and Costin 1971; Bowler and Polach 1971). These problems involve soil OM biodynamics in various landscape/climatic areas and soil types. Unlike wood and peat, where each annual tree ring and peat layer "conserves" the particular ${ }^{14} \mathrm{C}$ content of the moment of growth, soil horizons are characterized by constant replacement of $\mathrm{OM}$ along the profile, which leads to redistribution of ${ }^{14} \mathrm{C}$ ratios in different carbon-containing materials and soil fractions.

Zavelskiy (1975) believes that 1) soil OM cannot be used for ${ }^{14} \mathrm{C}$ dating; 2) soil OM reflects the mean residence time of ${ }^{14} \mathrm{C}$ in soil; and 3) soil OM consists of biologically active and biologically inert components. We suggest that the ${ }^{14} \mathrm{C}$ dates reflect a reliable mean age of soil buried by the biologically inert fraction of humus material. ${ }^{14} \mathrm{C}$ also enables us to use biologically active fractions to identify possible sample contamination (in an open system of buried soils).

We investigated buried soils and the reliability of their dating to clarify the suitability of soil material for dating, depending on burial conditions and the origin of sediments containing the soils. We examined soil horizons that included carbon-containing material of different origins, such as wood, coal, bones and carbonate concretions, which also help to establish control ages.

\section{METHODS}

To separate soil organics for dating, we employ Turin's method (Arslanov and Kozyreva 1976). $\mathrm{OM}$ is divided into the following fractions: 1) free humic acids - fulvic acids; 2) humic acids bound with $\mathrm{Ca}$ and $\mathrm{R}_{2} \mathrm{O}_{3}$ mobile species - fraction I; 3) humic acids bound with $\mathrm{R}_{2} \mathrm{O}_{3}$ stable forms (more firmly attached to the mineral fraction) - fraction II; 4) humin; and 5) soil remnant.

We sift a dry soil sample, ranging from 3 to $20 \mathrm{~kg}$, through a sieve (minimal cell size $=0.25 \mathrm{~mm}$ ) without grinding so as not to contaminate the sample with plant or animal organic remnants. Then, we mechanically remove foreign material (e.g., seeds, grass roots, insect remnants). The sample is inspected further under a binocular microscope and placed into 20-liter glass vessels; we then add $0.1 \mathrm{~N} \mathrm{NaOH}$ solution at room temperature. To precipitate clay particles, we add $40 \mathrm{~g}$ of $\mathrm{Na}_{2} \mathrm{SO}_{4}$. Pure water is added to each container to bring the volume to 10 liters. The mixture is stirred several times during the day and left overnight. The next day, the solution is siphoned and precipitated by adding concentrated $\mathrm{H}_{2} \mathrm{SO}_{4}$ and heating to $80^{\circ} \mathrm{C}$. The precipitate is collected, filtered with a Büchner funnel containing a double glass-fiber filter, washed in distilled water and dried 
at $105^{\circ} \mathrm{C}$. Benzene is synthesized from this fraction to obtain a ${ }^{14} \mathrm{C}$ age of fulvic acid fractions. The remaining soil is decalcified with $0.1 \mathrm{~N} \mathrm{H}_{2} \mathrm{SO}_{4}$ or with $0.1 \mathrm{~N} \mathrm{HCl}$ solution in the case of carbonate soils. Then it is washed with distilled water until no $\mathrm{Ca}^{2+}$ appears in filtrate. The decalcified soil is treated 2-3 times with $0.1 \mathrm{~N} \mathrm{NaOH}$ solution at room temperature. The alkaline solution is siphoned and humic acids precipitated by adding $0.1 \mathrm{~N} \mathrm{H}_{2} \mathrm{SO}_{4}$. Humic acids are then dried for production of benzene. This first fraction of humic acids is bound with $\mathrm{Ca}$ and mobile $\mathrm{R}_{2} \mathrm{O}_{3}$ forms. The remaining soil is treated alternately with $0.1 \mathrm{~N} \mathrm{H}_{2} \mathrm{SO}_{4}$ and $\mathrm{NaOH}$ solutions $(2-3$ times). The alkaline filtrate is collected and the second fraction of humic acids is separated, more firmly bound to mineral phases. Then the soil is placed into a stainless-steel water bath, mixed with $0.1 \mathrm{~N} \mathrm{NaOH}$ solution and heated to $80-90^{\circ} \mathrm{C}$ for $2-3 \mathrm{~h}$. This hot treatment is repeated $2-3$ times. The alkaline filtrate is siphoned and the humin fraction is prepared by the same separation methods. Finally, the soil remnant is washed with acidified water, dried at $105^{\circ} \mathrm{C}$ and dated.

Wood is pretreated by the standard method, which includes using $5 \% \mathrm{HCl}$ and $3 \% \mathrm{NaOH}$ solutions. Carbonate concretions are prepared for dating by first removing the outer $10-20 \%$, then washing in distilled water. The $\mathrm{CO}_{2}$ for ${ }^{14} \mathrm{C}$ dating is released by acid hydrolysis.

\section{RESULTS}

Mamonovo. We dated buried soil humus and wood from upright stumps from a section in the 10$11 \mathrm{~m}$ terrace of the valley of the Berd River, a tributary of the river Ob upstream of Novosibirsk, West Siberia (Fig. 1). The buried soil horizon with stumps is clearly evident $3 \mathrm{~m}$ above the river level in laminated alluvial sediments. A wood sample dated to $12,810 \pm 40 \mathrm{BP}$ (SOAN-1879A). Humic acids were obtained by alkaline treatment of the sample and dated separately to $12,220 \pm$ $100 \mathrm{BP}$ (SOAN-1879B). Another stump from the same horizon was dated at $12,450 \pm 55 \mathrm{BP}$ (SOAN-411). The soil humin fraction was dated at 12,300 \pm 45 BP (SOAN-1879C).

Krasniy Yar. The section is located on the Ob River $15-20 \mathrm{~km}$ from Novosibirsk (Fig. 2). Pleistocene sediments with buried soils containing upright stump remnants lie on a $35-\mathrm{m}$ terrace. The section is of particular interest for dating buried soils. The age of the terrace deposits was disputed until recently (Arkhipov et al. 1980; Martynov, Mizerov and Nikitin 1977; Nikitin 1970; Panychev 1979; Volkov and Arkhipov 1978); hence, many ${ }^{14} \mathrm{C}$ dates were measured from stump remnants preserved in the upper buried soil at the depth of $20 \mathrm{~m}$ from the terrace surface (Table 1).

TABLE 1. Dating Results for the Stump Horizon in the Krasniy Yar Section

\begin{tabular}{|c|c|c|c|}
\hline Lab no. & Material & Age (BP) & Year and lab of analysis \\
\hline St-6678 & Wood & $28,425 \pm 835$ & 1978, Swedish Geological Survey \\
\hline $\mathrm{T}-3024$ & Wood & $29,200 \pm 700$ & $\begin{array}{l}\text { 1978, Norwegian Technological Institute, } \\
\text { Trondheim }\end{array}$ \\
\hline GSC-2905 & Wood & $29,000 \pm 450$ & 1979, Geological Survey of Canada, Ottawa \\
\hline Vs-259 & Wood & $30,720 \pm 1200$ & 1978, Lithuanian NIGRI, Vilnius \\
\hline SOAN-1065A & Wood & $28,200 \pm 240$ & 1975, IGG SB AS USSR, Novosibirsk \\
\hline SOAN-1065B & $\begin{array}{l}\text { Humic acids of } \\
\text { wood }\end{array}$ & $28,600 \pm 340$ & 1975, IGG SB AS USSR, Novosibirsk \\
\hline SOAN-1456 & Wood & $29,410 \pm 250$ & 1977, IGG SB AS USSR, Novosibirsk \\
\hline SOAN-1457 & Wood & $30,870 \pm 300$ & 1977, IGG SB AS USSR, Novosibirsk \\
\hline SOAN-2002 & $\begin{array}{l}\text { Humic acids of } \\
\text { soil }\end{array}$ & $28,100 \pm 485$ & 1982, IGG SB AS USSR, Novosibirsk \\
\hline
\end{tabular}




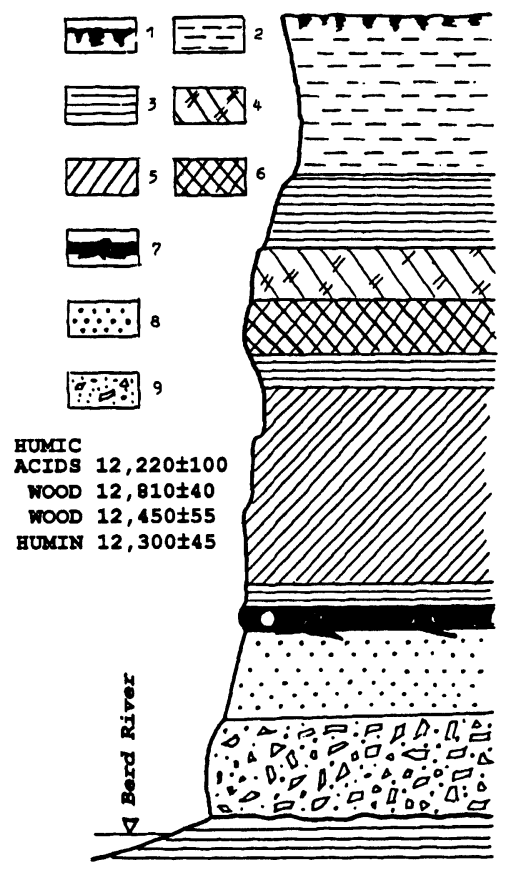

Fig. 1. Structure and age of the Berd River I terrace deposits at Mamonovo: 1 . recent soil; 2. sandy loam; 3 . clay; 4. strongly mineralized wood peat; 5 . loam; 6 . wood peat; 7. buried soil horizon with wood stumps; 8. sand; 9. crystalline schist debris

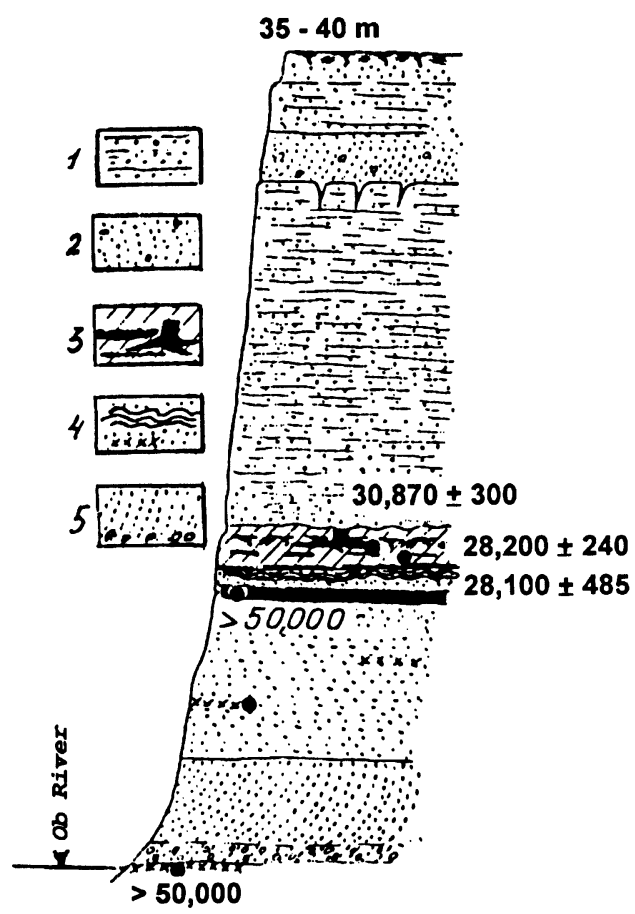

Fig. 2. Structure and age of the deposits of the $\mathrm{Ob}$ River $35 \mathrm{~m}$ terrace at Krasniy Yar: 1. interbedding of loam, sandy loam and fine-grained sand; 2 . non-equigranular sand; 3 . blue-gray loam with humus horizons and upright wood stumps; 4. fine-grained sand with humus horizons, wood stumps, interbedded detritus and gravel at the base; 5 . fluvial sands with lentils of washed-in detritus and gravel at the base

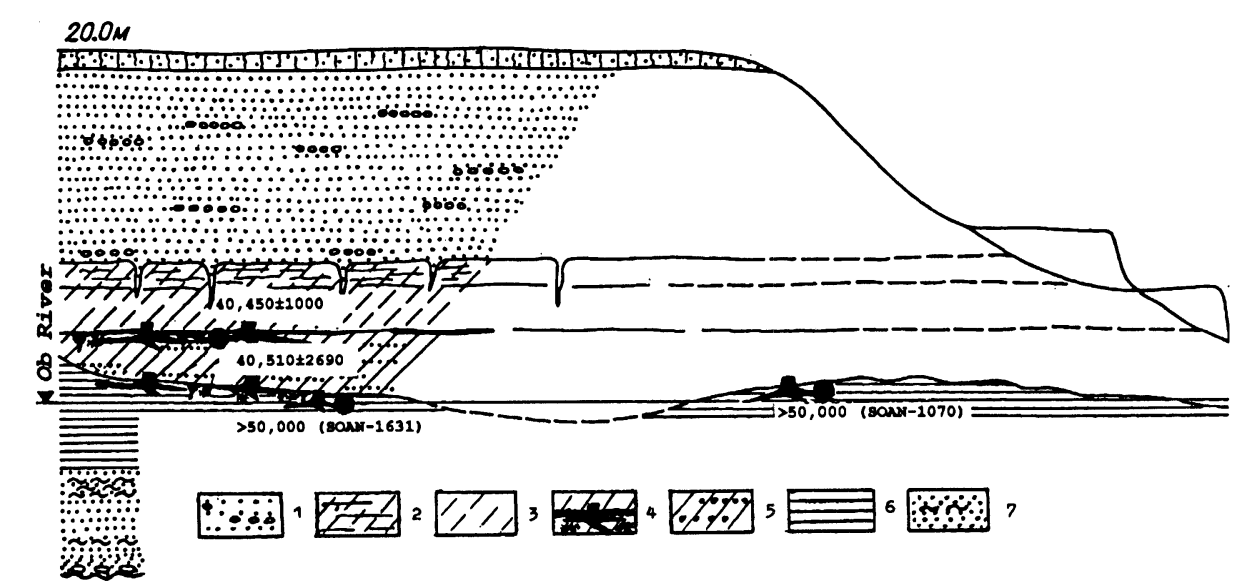

Fig. 3. Structure and the age of the Ob River II terrace deposits at Malyshevo: 1. gray quartz sand with gravel interbeds; 2. interbedded loam and sandy loam; 3. loam with sand interbeds; 4. humus loam with upright wood stumps; 5 . loam with sand and sandy loam interbeds, sometimes gravel; 6 . blue clay with interbeds of plant detritus; 7 . bedded gray sand 


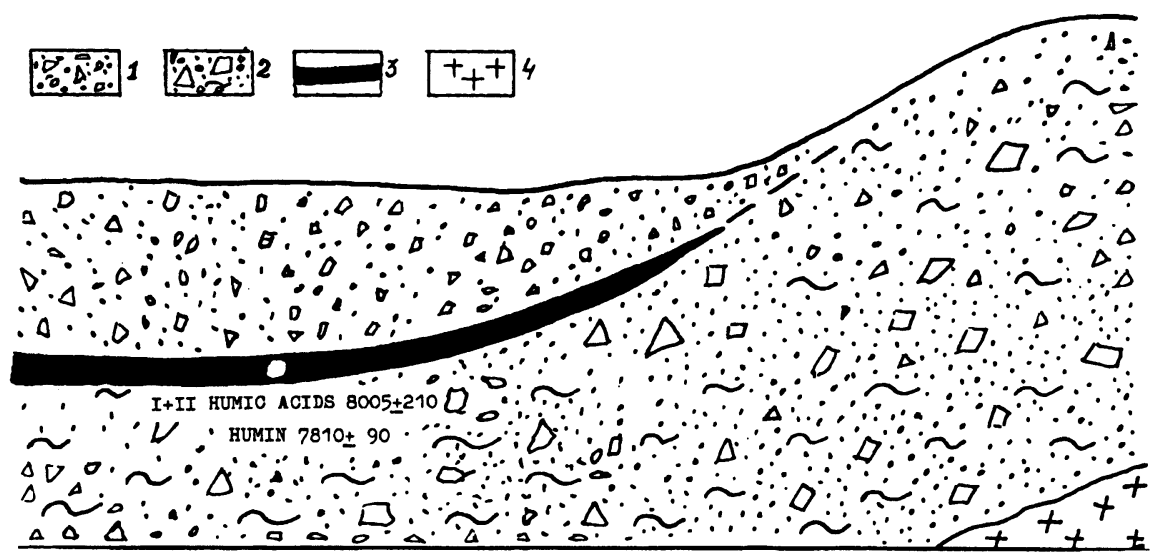

Fig. 4. Section of the deposits of the Elovka River debris cone, cape Goloustniy: 1. fine rock debris; 2. detrital-boulder deposits with sandy loam filler; 3. buried soil; 4. original deposits

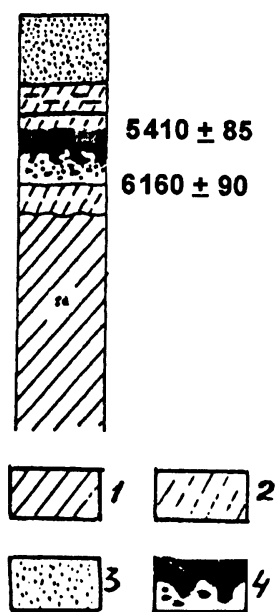

Fig. 5. Structure and age of the lacustrine deposits at Suminskoye: 1 loam of Fedosovskian suite $(\mathrm{Q} 1+2) ; 2$. sandy loam; 3 . sand; 4. buried soil horizon

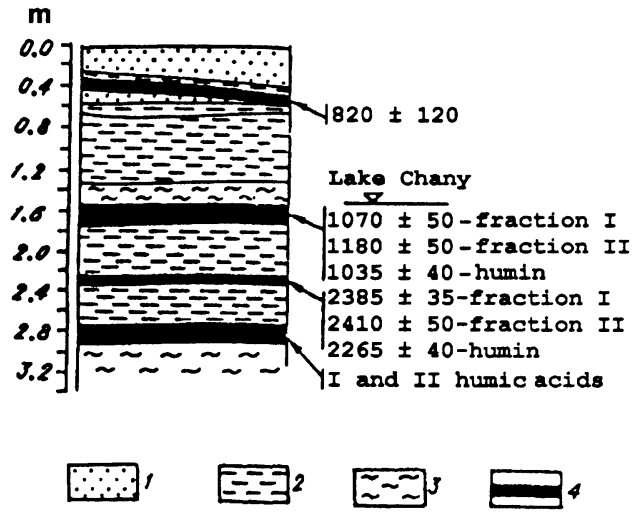

Fig. 6. Structure of the lacustrine deposits at Shirokaya Kurya: 1 . sand; 2 . sandy loam; 3 . silt; 4 . buried boggy soil

Malyshevo. The section of 20-m terrace of the Ob River in the Biysk-Barnaul depression (West Siberia) has three clear horizons, rich in plant remains (Fig. 3). The middle organic layer consists of buried soil with clear genetic horizons. The stumps above the soil yielded two ${ }^{14} \mathrm{C}$ ages for the horizon: wood: 40,450 $\pm 1000 \mathrm{BP}$ (SOAN-1632) and combined fractions I and II: 40,510 $\pm 2,690$ BP (SOAN-2001).

Goloustnoye. This section is located on the west coast of Lake Baikal, north of Cape Goloustniy (East Siberia). The buried soil is bedded among boulder-detrital deposits with sandy fill, forming 
the debris cone of the Elovka River (Fig. 4). Combined fractions I and II yielded a ${ }^{14} \mathrm{C}$ date of $7810 \pm 90 \mathrm{BP}$ (SOAN-1597); humin gave a date of $8005 \pm 210 \mathrm{BP}$ (SOAN-1597A).

Suminskoye. This section is located on the margin of the Suminskoye floodplain, Barabinsk lowland, West Siberia. Dates were measured on two humic fractions of the soil buried under lacustrine sands $1.0 \mathrm{~m}$ thick (Fig. 5). The age of the first fraction was $5410 \pm 85 \mathrm{BP}$ (SOAN-1966B).

Shirokaya Kurja. This section is in the coastal area of Malye Chany Lake near Shirokaya Kurja, Barabinsk lowland, West Siberia. Among the lacustrine deposits, three peat-bog soils were sampled at depths of $1.55-1.70$ and $2.70-2.90 \mathrm{~m}$, respectively (Fig. 6). The upper soil profile shows clear horizons that indicate a fairly long subareal break in the formation of the lacustrine deposits. From the upper part of an organogenic peatified horizon of this soil, three humus fractions were dated: fraction I = $1070 \pm 35 \mathrm{BP}$ (SOAN-2092A); fraction II = $1180 \pm 50 \mathrm{BP}(\mathrm{SOAN}-2092 \mathrm{~B})$; and humin fraction $=1035 \pm 40 \mathrm{BP}(\mathrm{SOAN}-2092 \mathrm{C})$. The middle soil profile is poorly developed, has a thin humus horizon and represents a short regressive stage in the development of the Chany Lake system. Soil humus fractions have the following ${ }^{14} \mathrm{C}$ ages: fraction $\mathrm{I}=2385 \pm 35 \mathrm{BP}$ (SOAN2091A); fraction II = $2410 \pm 50 \mathrm{BP}(\mathrm{SOAN}-2091 \mathrm{~B})$; and humin $=2265 \pm 40 \mathrm{BP}(\mathrm{SOAN}-2091 \mathrm{C})$. The lower soil horizon is dated by fractions I and II at $5530 \pm 210 \mathrm{BP}$ (SOAN-2090).

Iskitim. This section is located on the slope of the Berd River valley near Iskitim (West Siberia), in a unit of loess-like deposits exposed for marble mining. At 4.5-5.0 m depth, two buried soils separated by a loess-like loam ( $0.5 \mathrm{~m}$ thick) were traced (Fig. 7). The lower soil was deformed by frost-solifluction. The humus horizon was broken, folded and stretched with varying local intensity of humification. Small coal-like fragments, dated at 33,100 \pm 1600 BP (SOAN-165), occur as separate objects. At the surface of this soil horizon, a wooly rhinoceros skull was found; the collagen fraction was dated at 32,780 $\pm 670 \mathrm{BP}$ (SOAN-629). Humic acids of this soil horizon were dated to $29,000 \pm 450 \mathrm{BP}$ (IGAN-168).

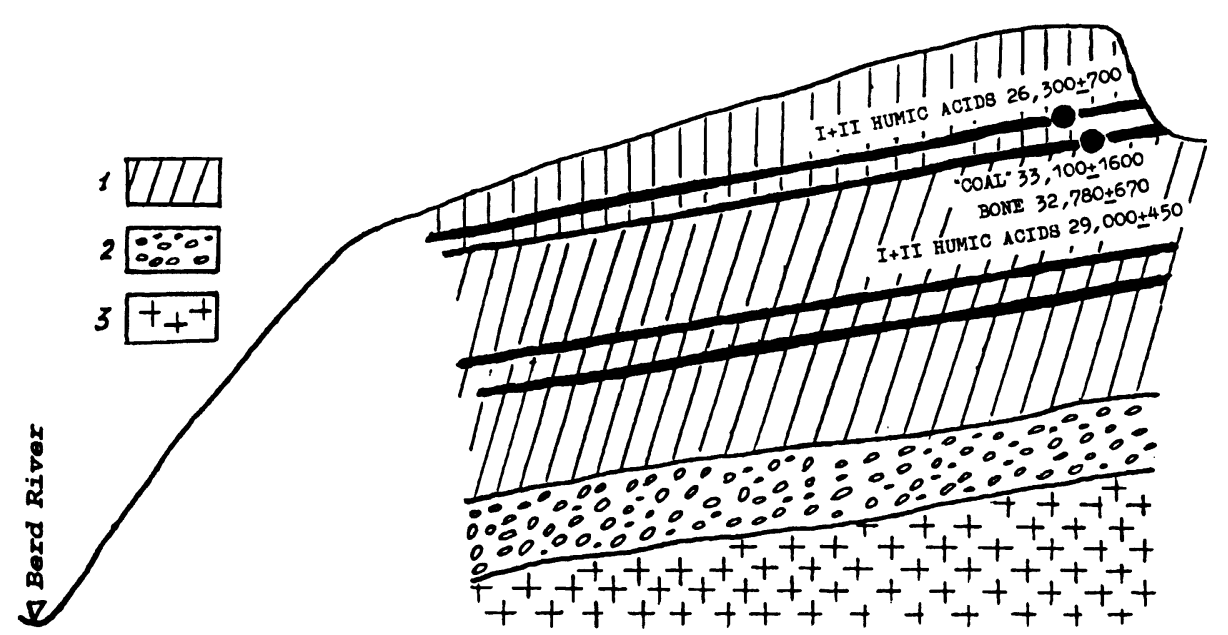

Fig. 7. Profile from marble quarry at Iskitim showing loess strips: 1. loess-like loam; 2. rounded pebbles; 3. original rock (marble)

Maslanino. This section is from the upper part of terrace I (above the floodplain) of the Berd River at Maslanino village (West Siberia). Buried soil lies beneath loess-like loam at $1.0 \mathrm{~m}$ depth (Fig. 8). The soil has a dark gray, $0.4-0.5-\mathrm{m}$-thick humus horizon and a thick carbonate-illuvial horizon. 
Carbonate lenses are slightly elongated, $1.5-2.0 \mathrm{~cm}$ in diameter. The concretions were dated at $8700 \pm 50 \mathrm{BP}(\mathrm{SOAN}-838)$ and the soil humic acid fraction dated at $4720 \pm 50 \mathrm{BP}$ (SOAN-837).

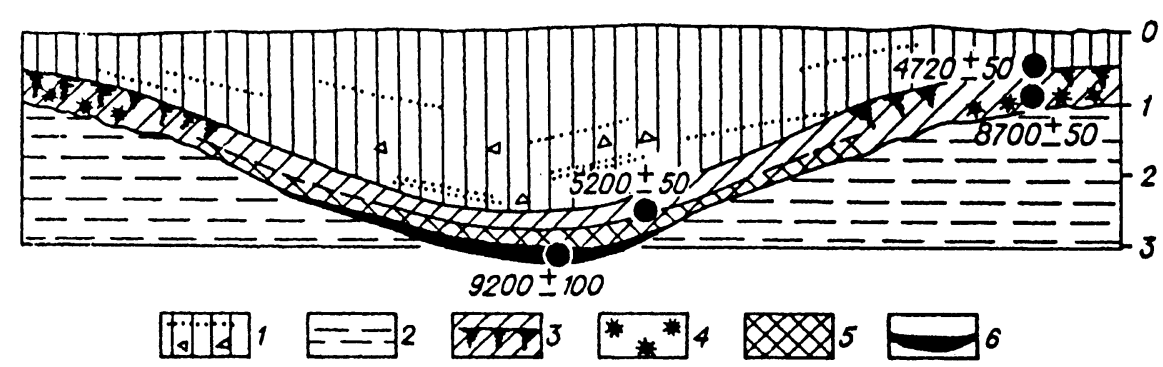

Fig. 8. Upper part of terrace I of Berd River deposits at Maslanino: 1. loam; 2. sandy loam; 3. buried soil; 4. calcareous concretion; 5 . gyttja; 6 . sapropel

Kuekhtanar. This section lies in the Chuya River valley near the mouth of the Kuekhtanar River between the Chuyan and Kurayan depressions of the Altai Mountains. The glacier descending from the Kurayan ridge along the Kuekhtanar Valley left an end moraine that formed the Chuya River. Consequently, thinly laminated lacustrine sediments were deposited upstream of the Chuya River. A $0.3-0.4-\mathrm{m}$-thick soil horizon developed above them, in turn overlapped by eolian sands, $0.5 \mathrm{~m}$ thick (Fig. 9). Soil humus fractions were dated as follows: fraction I $=6325 \pm 30 \mathrm{BP}$ (SOAN$1692 \mathrm{~A})$; fraction II = $6565 \pm 80 \mathrm{BP}(\mathrm{SOAN}-1692 \mathrm{~B})$; and humin $=5330 \pm 80 \mathrm{BP}(\mathrm{SOAN}-1692 \mathrm{C})$.

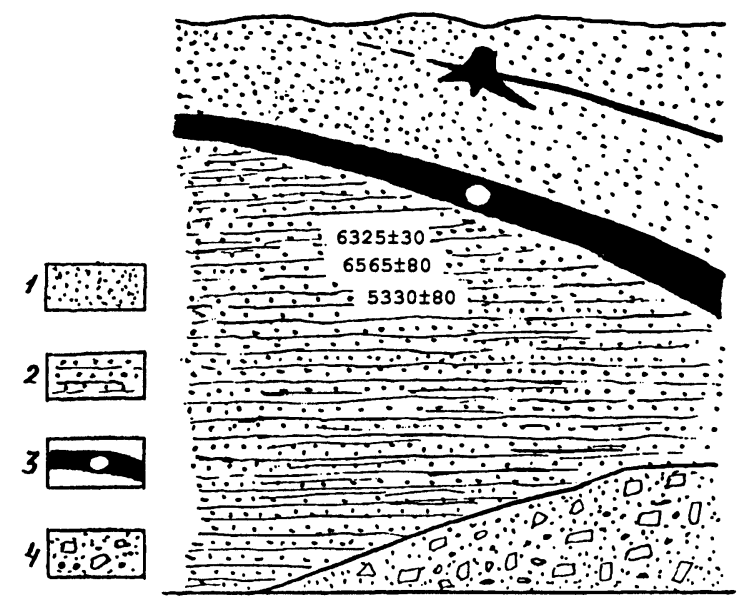

Fig. 9. Structure and age of Kuekhtanar River deposits: 1 . eolian sands; 2 . horizontal thin-laminated sands; 3. buried soil horizon; 4. detrital-boulder deposits

\section{DisCUSSION}

Buried soils often occur among Late Pleistocene and Holocene alluvial deposits; analysis of the sedimentation process shows that, in most cases, the soils formed on and within alluvial floodplain clays and loams. The physical structure of these deposits preserves soil organics and alluvial aggradation protects the underlying soil from addition of younger carbon. Under these circumstances, carbon-specific activity decreases only due to ${ }^{14} \mathrm{C}$ decay. Consequently, soil organics should be considered as a closed system with respect to ${ }^{14} \mathrm{C}$ exchange (Zavelskiy 1975), and ${ }^{14} \mathrm{C}$ ages will correspond to the mean time of the soil horizon formation. ${ }^{14} \mathrm{C}$ dates from soil $\mathrm{OM}$ in 
alluvial horizons-Krasniy Yar, Malyshevo and Mamonovo—-correspond well to wood ages (Fig. 10 ), or do not exceed statistical error limits.

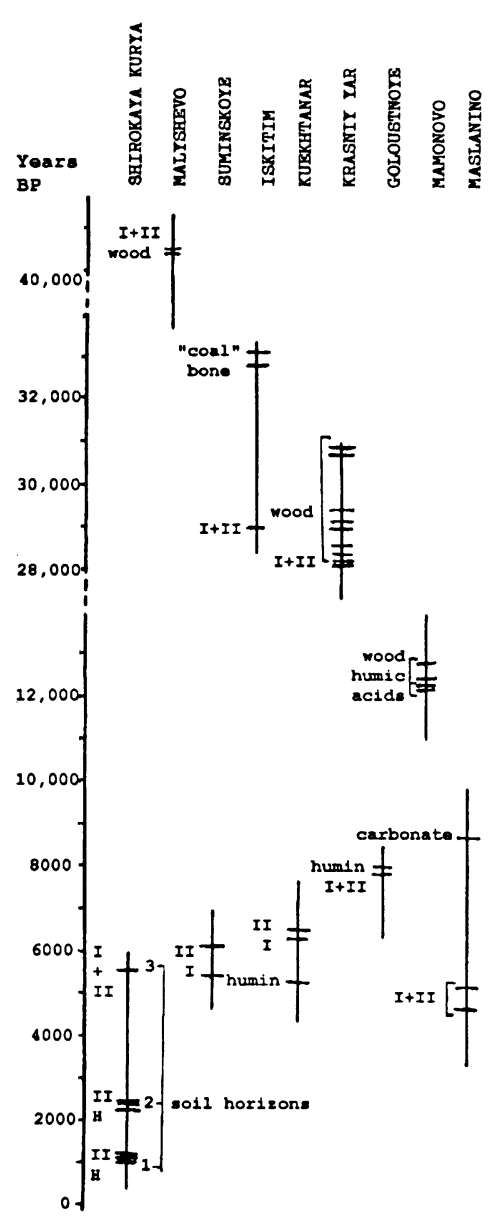

Fig. $10 .{ }^{14} \mathrm{C}$ age of soil horizons from different carbonaceous materials: $\mathrm{I}=$ fraction I; II = fraction II; $\mathrm{H}=$ humin
A similar conclusion can be drawn regarding soil samples from thick flood deposits. Thus, in the Cape Goloustniy section, the soil horizon was buried quickly in the flood deposits by a thick layer of boulder-detrital deposits, and lies beneath the present root system. Here, the ages of humin and humic acids do not exceed the statistical limits of the measurement, i.e., both fractions appear almost coeval. In contrast, the soil horizon in the Kuekhtanar section is overlain by a thin ( 0.5 $\mathrm{m}$ ) cover of eolian sands, which permits contamination of soil organics due to penetration of the present root system. In this case, the difference between the mean ages of fractions I and II and the humin date is 11 times greater than their combined standard deviations (far greater than laboratory measurement errors).

The peculiarities of humin behavior in the soil, because of which it is placed in a separate group of humus substances, are determined by bonding rather than chemistry (Vozbutskaya 1968). This suggests that, if the inflow of organics ceased at the time of soil horizon burial, then ${ }^{14} \mathrm{C}$ decreases only exponentially. In this case, the humin age will approximate the time of soil horizon formation and correspond to the age of other soil humus fractions; this is observed in ${ }^{14} \mathrm{C}$ data for soil organics in the Cape Goloustniy section. When the soil development has undergone an open-closed system ${ }^{14} \mathrm{C}$ exchange, age differences between soil fractions are much greater, which may indicate soil contamination. Humin yields artificially young ${ }^{14} \mathrm{C}$ ages, as these fractions are most sensitive to organic inflow. This is because humin consists of carbonized particles, formed from dead roots that have carbonized during seasonal wetting and drying. These particles are inert inclusions, isolated from soil processes. Their epigenetic formation results from the penetration of the modern root system into the buried soil layer, which only minimally affects the age of soil humic acid fractions. Thus, dates from the Kuekhtanar section are probably artificially young. Unfortunately, the lack of control dates on charcoal or bone does not allow us to estimate this effect. ${ }^{14} \mathrm{C}$ ages should be considered only as minimum ages for soil horizons.

We found similar burial conditions in the loess deposits at Iskitim. Because of the presence of charcoal and bone in the lower part of the section, we were able to estimate the contaminant effect on the humic acids. Stratigraphic agreement with bone and charcoal dates enabled us to correlate the frost-solifluctional deformations of the lower soil horizon, and the loess accumulation process above them, with the Interkarginian (Konoshelian) cooling (Kind 1974), when charcoal-like plant remains intruded into the soil. The lower soil probably formed during the Karginian warming optimum (41,000 BP). Konoshelian cooling was significant in degree, but not long-lasting, and was replaced by Late-Karginian warming when the upper soil of Iskitim formed. Loessial loam $(0.5 \mathrm{~m})$ separating the soil horizons would not have effectively prevented root penetration from the upper 
Iskitim soil. Thus, the lower soil, at least during the Late-Karginian, represented an open carbonexchange system. Here, the age of the humic acids of the lower soil is significantly underestimated, and does not reflect the true time of soil formation. A similar situation is observed in the Maslanino and Suminskoye sections, where the soil horizons are overlain by a thin sediment cover. This increases the likelihood of contamination of soil organics by the present root system. In contrast, soil horizons in Cape Goloustniy and Shirokaya Kurya are beneath the zone of penetration of the present root system. Here, the ages of humin and humic acids are beyond the range of statistical error, and the fractions appeared almost coeval.

Soil carbonates present particular problems in ${ }^{14} \mathrm{C}$ dating. Dates from Maslanino, as well as other sections, show great variation. It is well known that carbonic acid formed from the decay of organic remnants binds with $\mathrm{Ca}$ in solution, promoting conversion of insoluble carbonates into more soluble bicarbonates. In wet seasons, $\mathrm{Ca}$ bicarbonate migrates from the upper part of the section to the lower one. At depth, $\mathrm{pCO}_{2}$ decreases and the solution precipitates, resulting in the formation of carbonate concretions (Gerasimov and Glazovskaya 1960). However, in some cases, this process is interrupted by the inflow of external $\mathrm{Ca}$ bicarbonate with different ${ }^{14} \mathrm{C}$ content, which leads to age errors. Bowler and Polach (1971) studied ${ }^{14} \mathrm{C}$ dating of carbonate soils in southeast Australia, and concluded that the ${ }^{14} \mathrm{C}$ age of carbonates is younger than the age of deposits on which they formed. The degree of age difference markedly increases from dry to wetter regions. This is due to isotopic exchange in the soil-atmosphere system. The rate of ${ }^{14} \mathrm{C}$ exchange depends on carbonate permeability, the degree of soil activity, plant cover and climate. In wet regions, the ${ }^{14} \mathrm{C}$ age of soil carbonates is greatly underestimated; in arid regions, it is closer to the true age of pedogenesis.

\section{CONCLUSIONS}

We conclude the following:

1. In alluvial and flood deposits, where soil burial occurs relatively quickly, and the thickness of overlying sediments is sufficiently great to remove the buried soil from the zone of penetration of the present root system, ${ }^{14} \mathrm{C}$ dates of soil organic fraction are valid.

2. In loess deposits accumulated with relatively slow inflow of mineral mass during continuous soil formation, the soil system remains open for a long period; this changes the ${ }^{14} \mathrm{C}$ content of different paleosol fractions and results in significant age underestimation.

3. Our results showed uneven distribution of ${ }^{14} \mathrm{C}$ in different paleosol $\mathrm{OM}$ fractions; its deficiency is particularly great in fraction II, which is bound more tightly with soil minerals.

4. Dating of each soil organic fraction does not permit quantitative estimates of contamination; however, it enables identification of soil contamination by foreign carbon and qualitative evaluation of the validity of dating.

\section{REFERENCES}

Arkhipov, S. A., Astahov, V. I., Volkov, I. A., Volkova, V. S. and Panychev, V. A. 1980 Paleogeography of the West Siberian Plain During the Late Zyrjanka Glacial Maximum. Novosibirsk, Nauka: 110 p.

Arslanov, Kh. A. 1987 Radiocarbon: Geochemistry and Geochronology. Leningrad: 298 p.

Arslanov, Kh. A., Gerasimov, I. P. and Zubkov, A. I. 1970 Blackearth dating by the ${ }^{14} \mathrm{C}$ method. Presentations of the Academy of Sciences of the USSR 192(5): 1141-1144.

Arslanov, Kh. A. and Kozyreva, M. G. 1976 On the problem of radiocarbon dating modern soils. In The
Northwestern European USSR. Leningrad: 99-113. Bowler, I. M. and Polach, H. A. 1971 Radiocarbon analyses of soil carbonates: An evaluation from paleosols in southeastern Australia. In Yaalon, D. H., ed., Paleopedology: Origin, Nature and Dating of Paleosols. Jerusalem, International Society of Soil Science: 97-108.

Campbell, C. A., Paul, E. A., Rennie, D. A. and McCallum, L. I. 1967 Applicability of the carbon dating method of analysis to soil humus studies. Soil Science 104: 217-224. 
Chichagova, O. A. 1985 Radiocarbon Dating of Soil Humus: Its Method and Use in Pedology and Paleogeography. Moscow, Nauka: 158 p.

Costin, A. V. and Polach, H. A. 1969 Dating soil organic matter. Applicability to buried soils in the Koscinski area N.S.W. Atomic Energy in Australia 12: 7413.

Geyh, M. A., Bensler, I. H. and Roeschman, G. 1971 Problems of dating Pleistocene and Holocene soils by radiometric methods. In Yaalon, D. H., ed., Paleopedology: Origin, Nature and Dating of Paleosols. Jerusalem, International Society of Soil Science: 6375.

Gerasimov, I. P. and Chichagova, O. A. 1971 Some problems of the ${ }^{14} \mathrm{C}$ dating of soil humus. Pedology 10: 3-11.

Gerasimov, I. P. and Glazovskaya, M. A. 1960 Principles of Pedology and Soil Geography. Moscow, Geografgiz: $140 \mathrm{p}$.

Kind, N. V. 1974 Late Anthropogene Geochronology by Isotope Data. Moscow, Nauka: $256 \mathrm{p}$.

Martynov, B. A., Mizerov, B. V. and Nikitin, V. P. 1977 Geomorphological Structure of the Ob Valley Near Novosibirsk. Novosibirsk, IGG SB USSR Academy of Sciences: $35 \mathrm{p}$.

Nikitin, V. P. 1970 Quaternary floras of West Siberia (seeds and fruits). In The History of Flora Development in the Extraglacial Zone of the West Siberian Plain During Late Pliocene and Quaternary Times. Moscow, Nauka: 245-311.

Panychev, V. A. 1979 Radiocarbon Chronology of Alluvial Deposits of the Prealtai Plain. Novosibirsk, Nauka: 102 p.

Polach, H. A. and Costin, A. B. 1971 Validity of soil organic matter radiocarbon dating: Buried soils in Snowy Mountains, southeastern Australia as example. In Yaalon, D. H., ed., Paleopedology: Origin, Nature and Dating of Paleosols. Jerusalem, International Society of Soil Science: 89-96.

Scharpenseel, H. W. 1971 Radiocarbon dating of the soil. Pedology 1: 34-42.

Tamm, C. O. and Östlund, H. G. 1960 Radiocarbon dating of soil humus. Nature 185: 706.

Volkov, I. A. and Arkhipov, S. A. 1978 Quaternary Deposits of the Novosibirsk Region. Novosibirsk, IGG SB USSR Academy of Sciences: 89 p.

Vozbutskaya, A. E. 1968 Soil Chemistry. Moscow: 426 p.

Zavelskiy, F. C. 1975 Radiocarbon dating and theoretical models of carbon turnover in the soils. Proceedings of the Academy of Science, USSR, Geography Series 1: 27-34. 